\title{
Effects of Hot Water on Breaking Seed Dormancy of Senna obtusifolia from Bichi, Nigeria, in Green House Conditions.
}

\author{
Abdulazeez, $\mathrm{A}^{1}$ \\ ${ }^{l}$ ( Department of Agricultural Education, Federal College of Education (Technical) Bichi, Nigeria).
}

\begin{abstract}
Hard or impermeable seed coat is a mechanism that insures the survival of Senna obtusifolia. Senna obtusifolia is traditionally and economically important plant. Information on ways to break seed dormancy would be useful for uniform germination and post emergence management of the plant. In July 2016, a green house trial was conducted at Department of Agricultural Education, Federal College of Education (Technical) Bichi to determine the effects of hot water $\left(\left(100^{\circ \mathrm{C}}\right)\right.$ at different length of time that would break the seed dormancy of Senna obtusifolia. Dip Senna obtusifolia seeds in hot water $\left(\left(100^{\circ C}\right)\right.$ for 1, 2, 3, 4, 5, 6, 7, 8, 9, 10, $11,12,13,14,15,16,17,18,19$ and 20 minutes and dip seeds in ordinary water for 12 hours were studied for fourteen days, and direct sowing (untreated) served as control. The experimental design used was completely randomized with three replications, Parameters considered include days to germination and percentages of germinated seeds per treatment. Breaking dormancy/germination frequencies for the same treatment were grouped and expressed as percentage. Results per treatment were analyzed through analysis of variance (ANOVA). All the hot water treatments (except dip for one minute) and dip for 12 hours in ordinary/normal water initiated their germination (100\%) three days after sowing. Dip for one minute and direct (untreated) seeds initiated $30 \%$ germination four days after sowing. Thus hot water dips at $100^{\circ \mathrm{C}}$ for length of time from 2 to 20 minutes and dip for 12 hours in ordinary water are recommended for breaking seed dormancy of Senna obtusifolia from Bichi, Nigeria.
\end{abstract}

Keywords: dormancy, germination, green house, hot water senna obtusifolia seeds, time,

\section{Introduction}

Dormancy is the arrested development and reversible rest period of plant organs, either of a seed or any of the vegetative part. Dormancy is not an absolute block to germination but an adaptation to evade unfavourable environmental conditions for a period of time (Gopal, 1990). Many previous researchers (Ameer, et al, 2013, Osman, et al, 2004 and Gopal, 1990) reported that hard or impermeable seed coats may be removed by long leaching action of soil-water, the activities of soil animals, biochemical changes of seed-coats during ageing, filing, rolling over sand or any abrasive substance, soaking in water, boiling in hot water and treating with commercial sulphuric acid. Senna obtusifolia belong to the family Fabaceae/Leguminosae. There are over 400 species of Senna/Cassia. Most are indigenous to North, Central and South America, and Africa, but it's now found in tropical and subtropical regions of all continents, except Europe. Some are native to South Asia, particularly India and Ceylon, and now widely cultivated in the tropics as well as being an ornamental tree in Southern Florida, the West Indies and Central and South America. Senna grows from seed and requires plenty of sun (Senna herbal Encyclopedia, 2016). All ancient cultures, including the Aztecs, Asians and Africans have used infusions of the senna species as a laxative. It is still an ingredient in several over-the-counter laxatives. Senna plant is used to relieve constipation, for skin problems, jaundice, bronchitis, liver diseases, anemia and urinary ailments (Senna herbal Encyclopedia, 2016). The young tender leaves of senna are used as vegetable throughout Africa (Irwin and Barneby, 1982) and as meat substitute in Sudan (Becker, 1986). Senna plant contained reasonable percentages of crude protein, mineral elements, energy and roughage-fibre acceptable to ruminant- herbivorous- Chinchilla rabbits (Abdulazeez, et al, 2016). The form of dormancy in Senna obtusifolia seed is physical impermeability of seed coat to water. Therefore the objective of this trial was to identify the length of time hot water $\left(100^{\circ \mathrm{c}}\right)$ would break seed dormancy (seed coat) of Senna native to Bichi, Nigeria under green house conditions. Senna grows wild in Bichi and Northern Nigeria in general.

\subsection{Materials}

\section{Materials and Methods}

Materials used for this trial include Senna obtusifolia seeds, lighter, thermometer $\left(100^{\circ \mathrm{C}}\right)$, ordinary water, aluminum pot, kerosene stove, transparent polythene bags, sandy soil and glass measuring cylinder $(1000 \mathrm{ml})$.

\subsection{Methods}

A total of 330 Senna obtusifolia seeds were obtained in February 2015 from brownish mature dry pods of uncultivated Senna obtusifolia plants in practical farm of Department of Agricultural Education, Federal 
Effects of Hot Water on Breaking Seed Dormancy of Senna obtusifolia from Bichi, Nigeria, in ....

College of Education (Technical) Bichi $\left(8^{0} 14^{\mathrm{I}}-12^{0} 14^{\mathrm{I}} \mathrm{E}\right.$ and $\left.12^{0} 14^{\mathrm{I}}-14^{0} 13^{\mathrm{I}} \mathrm{N}\right)$. The trial was carried out in green house of the department in July 2016. Sixty six transparent polythene bags $(12 \mathrm{~cm} \times 10 \mathrm{~cm} \times 12 \mathrm{~cm}$ each) were filled with light brown sandy soil, watered and arranged in three replicates thus twenty two treatments per replicate. Three hundred Senna obtusifolia seeds were dipped in $500 \mathrm{ml}$ of boiling water at $100^{\circ \mathrm{C}}$. Every other minute from the first to the last twenty minutes, fifteen seeds were taken and sown at five seeds per replicate per sand filled transparent polythene bag. Senna obtusifolia seeds soaked in ordinary water for twelve hours and untreated seeds were also sown. The sown seeds in the polythene bags were left in the green house. The breaking of dormancy/germination was observed daily early in the morning for a period of fourteen days. Days to germination were noted and the number of seeds germinated was counted. A seed was counted as broken dormancy/germinated when it showed radical that was at least the length of the seed. Breaking dormancy/germination frequencies for the same treatment were grouped and expressed as percentage. Results per treatment were analyzed, the actual difference (AD) was computed at $5 \%$ probability and significance and non significance were denoted as * and NS respectively. 3 replis. represented three replications. The treatments are:

$\mathrm{T}_{\mathrm{o}}$ - control (direct sowing)

$\mathrm{T}_{1}$ - hot water treatment for 1 minute

$\mathrm{T}_{2}$ - hot water treatment for 2 minutes

$\mathrm{T}_{3}$ - hot water treatment for 3 minutes

$\mathrm{T}_{4}$ - hot water treatment for 4 minutes

$\mathrm{T}_{5}$ - hot water treatment for 5 minutes

$\mathrm{T}_{6}$ - hot water treatment for 6 minutes

$\mathrm{T}_{7}$ - hot water treatment for 7 minutes

$\mathrm{T}_{8}$ - hot water treatment for 8 minutes

$\mathrm{T}_{9}-$ hot water treatment for 9 minutes

$\mathrm{T}_{10}$ - hot water treatment for 10 minutes

$\mathrm{T}_{12}$ - hot water treatment for 12 minutes

$\mathrm{T}_{13}$ - hot water treatment for 13 minutes

$\mathrm{T}_{14}$ - hot water treatment for 14 minutes

$\mathrm{T}_{15}$ - hot water treatment for 15 minutes

$\mathrm{T}_{16}$ - hot water treatment for 16 minutes

$\mathrm{T}_{17}$ - hot water treatment for 17 minutes

$\mathrm{T}_{18}$ - hot water treatment for 18 minutes

$\mathrm{T}_{19}$ - hot water treatment for 19 minutes

$\mathrm{T}_{20}$ - hot water treatment for 20 minutes

$\mathrm{T}_{21}$ - soak in ordinary water for 12 hours (SW24H)

\section{Results}

According to the results of variance analysis, the effects of treated and untreated senna obtusifolia seeds on germination rate was highly significant $(\mathrm{p}=0.05)$. Generally all hot water treatments (except dip for one minute) and soak in ordinary water for 12 hours enhanced germination of the seeds compared to control treatment (direct sowing). Results indicated that Senna obtusifolia seeds germination increased with increasing length of time in hot water and in ordinary water without damaging effect on both seeds cotyledons and embryo. It was observed that maximum number of germinated seeds $(15=100 \%)$ was found with dips in hot water for length of time from two to twenty minutes and with seeds soaked in ordinary water for twelve hours, whereas dips in hot water for one minute and untreated seeds showed the minimum number of germinated seed $(8=$ $53.3 \%)$ and $(7=46.6 \%)$ respectively.

Table 1. Effect of hot water at different length of time and soaking in ordinary water for 12 hours on breaking dormancy (germination) of Senna seeds.

\begin{tabular}{|lcccc|}
\hline $\begin{array}{c}\text { Treat- } \\
\text { ments }\end{array}$ & $\begin{array}{c}\text { total sown- } \\
\text { Per 3 replis. }\end{array}$ & $\begin{array}{c}\text { total germination } \\
\text { Per 3 replis. }\end{array}$ & $\begin{array}{c}\text { germination } \\
(\%)\end{array}$ & $\begin{array}{c}\text { days to } \\
\text { germination }\end{array}$ \\
\hline $\mathrm{T}_{\mathrm{o}}$ & 15 & $7^{*}$ & $46.6^{*}$ & 4 \\
$\mathrm{~T}_{1}$ & 15 & $8^{*}$ & $53.3^{*}$ & 4 \\
$\mathrm{~T}_{2}$ & 15 & $15 \mathrm{NS}$ & $100 \mathrm{NS}$ & 3 \\
$\mathrm{~T}_{3}$ & 15 & $15 \mathrm{NS}$ & $100 \mathrm{NS}$ & 3 \\
$\mathrm{~T}_{4}$ & 15 & 15 & 100 & 3 \\
$\mathrm{~T}_{5}$ & 15 & 15 & 100 & 3 \\
$\mathrm{~T}_{6}$ & 15 & 15 & 100 & 3 \\
$\mathrm{~T}_{7}$ & 15 & 15 & 100 & 3 \\
$\mathrm{~T}_{8}$ & 15 & 15 & 100 & 3 \\
$\mathrm{~T}_{9}$ & 15 & 15 & 100 & 3 \\
$\mathrm{~T}_{10}$ & 15 & 15 & 100 & 3 \\
\hline
\end{tabular}




\begin{tabular}{|lcccc|}
\hline $\mathrm{T}_{12}$ & 15 & 15 & 100 & 3 \\
$\mathrm{~T}_{13}$ & 15 & 15 & 100 & 3 \\
$\mathrm{~T}_{14}$ & 15 & 15 & 100 & 3 \\
$\mathrm{~T}_{15}$ & 15 & 15 & 100 & 3 \\
$\mathrm{~T}_{16}$ & 15 & 15 & 100 & 3 \\
$\mathrm{~T}_{17}$ & 15 & 15 & 100 & 3 \\
$\mathrm{~T}_{18}$ & 15 & 15 & 100 & 3 \\
$\mathrm{~T}_{19}$ & 15 & 15 & 100 & 3 \\
$\mathrm{~T}_{20}$ & 15 & 15 & 100 & 3 \\
$\mathrm{~T}_{\text {SW24H }}$ & 15 & 15 & 100 & 3 \\
Mean & 15 & 14.32 & 95.45 & \\
$\mathrm{SEd}$ & - & 4.6 & 5.6 & \\
$\mathrm{AD} \mathrm{P}=0.05$ & 7.0 & 6.7 & \\
\hline
\end{tabular}

\section{Discussion}

Germination is the process by which the embryo wakes from its dormant state, emerges and develops from the seed-embryo of those essential structures which indicate its ability to produce a normal plant under favourable conditions (Gopal, 1990). The results of the trial indicated that the seeds of Senna obtusifolia (fig. 1) obtained from natural environment of Federal College of Education (Technical) Bichi possess impermeable seeds coats that need to be broken before the seeds could germinate. Breaking down impermeability of seed coat by means of boiling in water for certain length of time and soaking in ordinary water for twelve hours resulted in considerable increase in imbibitions and germination percentage (by 100\%) in relatively short time. Percentage of the seed germination increased (53.3 to 100\%) with increasing length of time $\left(\mathrm{T}_{1}\right.$ to $\left.\mathrm{T}_{20}\right)$ in hot water without damaging effect on the seed cotyledon and embryo (Table 1, column 4 fig. 2). It was observed that maximum number of germinated seeds (15) was found with dips in hot water at $100^{0 \mathrm{c}}$ for length of time from two to twenty minutes and soaked seeds in ordinary water for twelve hours whereas the dips in hot water for one minute and untreated seeds (control) showed the minimum $(53.3 \%=8$ and $46.6 \%=7$ respectively) number of germinated seed (table 1 columns 4 and 5). These results are in agreement with the findings of Ameer et al (2013 in Cassia auriculata), Sedigheh et al (2009) in Rubia tinctorum, Demel (1995) in five Senna species and Osman (2004) in Lupinus varius L. who reported that seed germination increased with increasing water temperature and soaking period. Seed germination is a critical step to achieve economic success in Senna plant production. Total germination of Senna obtusifolia seed lot dictates total plant production (harvest) for ruminant-livestock feed (hay for Chinchilla rabbits), china coffee, fire wood, landscaping and for treatment of diseases. This trial concluded that sowing Senna obtusifolia seeds treated at $100^{\circ \mathrm{c}}$ for length of time from two to twenty minutes and soaked in ordinary water for twelve hours will help to achieve uniform seed germination for easy senna seedling and post seedling management, good harvest and higher income.

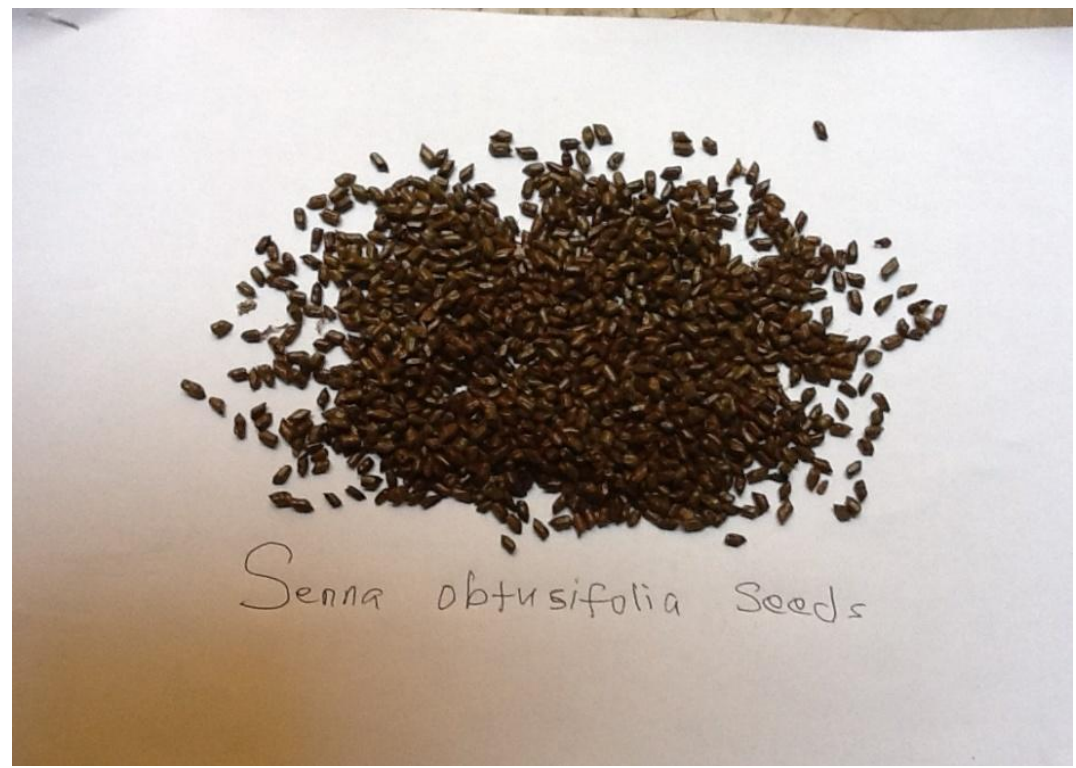

Fig.1. Dormant Senna obtusifolia seeds native to Bichi, Nigeria 


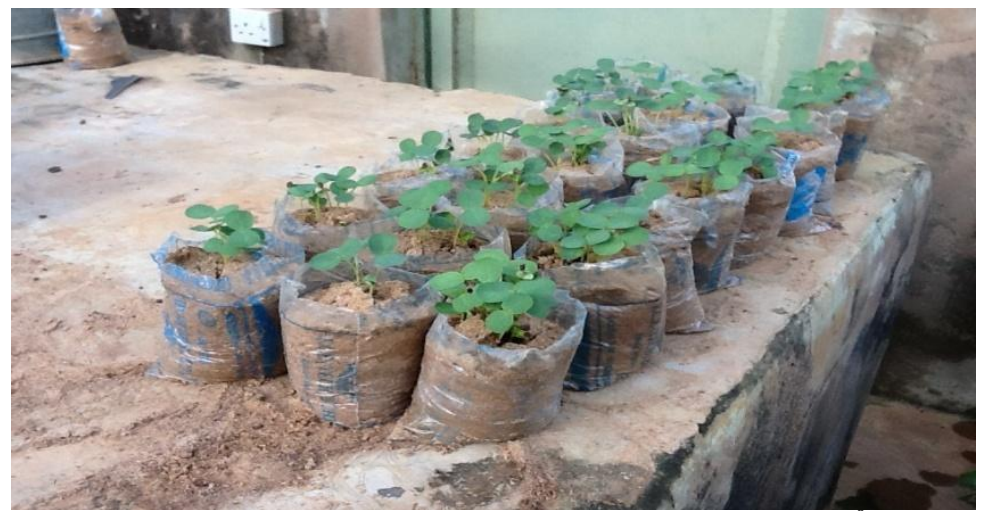

Fig. 2. Seedlings of germinated Senna obtusifolia seeds treated in hot water $\left(100^{\mathrm{oc}}\right)$ for length of time (one to twenty minutes), soaked for twelve hours in ordinary water and untreated (control) under green house conditions.

Books

\section{References}

[1] Gopal , C.D.E (1990). Fundamentals of Agronomy. Institute of Agriculture: Visva-Bharati, India. Oxford and IBH Pub. Company. PVT, Ltd. New Denhi. Journal Papers

[2] Ameer J.B.M, Vijayakumar, A, and Sejvaraju, P. (2013). Standardization of Seed Dormancy breaking treatment in Senna (Cassia auriculata). Journal of plant breeding and crop science. Vol. 5(11) pp.220-223 www. Academicjournals.org/JPBCS

[3] Osman K, Sadik, C, and Veli O (2004). Influence of seed coat treatment on germination and early seedling growth of Lupinus varius L. Pak. J.Bot. 36(1):65-74.

[4] Senna Herbal- Encyclopedia.File:///.C:/users/USERdocument/sennacultivation4.html.

[5] Irwin, H.S and Barneby R.C (1982). The American Cassiinae. Memoirs of the New York. Botanical Garden. 25: 1-918

[6] Becker B (1986). Wild plant for human nutrition in the Sahelian zone of arid environments. 11(1):61-64

[7] Abdulazeez, A and O.A. Abdulazeez (2016). Replacement of dry Senna obtusifolia for wheat offal in the diets of chinchilla rabbits. An indirect biological control of Senna. IOSR. Agriculture and Veterinary Science: Vol.9.issue 4.ver.11. http://www.iosrjournals.org/iosrjavs/pages/9(4)ver.11

[8] Sedigheh, S, Zoheir, Y, fakhr, M, and Hassan M.A. (2009). Study methods of dormancy breakling and germination of common Madder (Rubia tinctorum L). seed in laboratory conditions. Botany Research internationals. 2(1):7-10.

[9] Demel T. (1995). The effect of different pre-sowing seed treatments, temperature and light on the germination of five senna species from Ethiopia. Teketay, D. New forest (1996) 11:155. Doi:10.1007/BF00033411. 